\title{
ANALISIS PEMIKIRAN MICHAEL GORMAN TENTANG FIVE NEW LAWS OF LIBRARIANSHIP
}

\author{
Ahmad Anwar*
}

Pengutipan: Anwar, A. (2018). Analisis pemikiran Michael Gorman tentang Five New Laws of Librarianship. Khizanah al-Hikmah : Jurnal Ilmu Perpustakaan, Informasi, dan Kearsipan, 6(1), 67-75.

DOI: 10.24252/kah.v6a1a7

\author{
*Akademi Keperawatan Notokusumo, Yogyakarta \\ aan_whn@yahoo.com
}

\begin{abstract}
ABSTRAK
Pemikiran-pemikiran para ilmuwan perpustakaan telah banyak mempengaruhi perkembangan ilmu perpustakaan. Hal tersebut dikarenakan ilmu perpustakaan merupakan interdisplinary studies sehingga dapat mengkolaborasikan berbagai disiplin ilmu. Beberapa tokoh yang cukup berpengaruh dalam pengembangan konsep perpustakaan tersebut diantaranya adalah S.R. Ranganathan dan Michael Gorman. Melalui kajian ini dapat dilihat bahwa pemikiran dari Michael Gorman melalui five new laws of librarianship mampu menghadirkan dan menginterpretasikan kembali kebenaran dari konsep five laws of library science Ranganathan. Perbandingan mendasar dari kedua konsep tersebut adalah Gorman menekankan kepada konsep layanan masa kini sedangkan Ranganathan masih berfokus kepada pemanfaatan koleksi serta sarana prasarana pendukungnya. Hal terpenting yang dapat dilakukan saat ini adalah dengan mengaktualisasikan konsep five new laws of librarianship guna pengembangan perpustakaan di Indonesia
\end{abstract}

Kata kunci: Michael Gorman; konsep Five Laws of Librarianship; Ranganathan

\section{ABSTRACT}

The scientist thoughts have been influenced by the development of the library science. This is for the library science is an interdisciplinary study so that it can collaborate with many other discipline of knowledge. Some prominent figures who have influenced in the development of library concept; they are S.R. Ranganathan and Michael Gorman. Through this study, it can be seen that Michael Gorman thought through five new laws of librarianship can present and re-interpret the truth from five laws of library science concept of Ranganathan. The basic comparison from those two concepts is that Gorman emphasizes on the concept of today's services while Ranganathan still focuses on the collection's usage and its supporting facilities. However, the most important thing to do by this time is to actualize five new laws of librarianship concept to develop libraries in Indonesia.

Keywords: Michael Gorman, the Five Laws of Librarianship; Ranganathan

\section{PENDAHULUAN}

Ilmu Perpustakaan terus mengalami perkembangan dari masa ke masa, hal ini tidak terlepas dari kajian ilmu perpustakaan sebagai interdisplinary studies sehingga mampu mengambil dan memanfaatkan keilmuan lainnya. Ilmu Perpustakaan dikenal pertama kali pada tahun 1887 atas inisiatif dari Melvin Dewey melalui pendidikan kepustakawanan di Columbia College. 
Ilmu ini merupakan gabungan dari ilmu matematik, logika, linguistik, semantik, teori informasi, dan cybernetics (Qalyubi, 2007: 63). Sudah sangat lazim suatu disiplin ilmu meminjam, memodifikasi dan mengadaptasi disiplin ilmu lainnya (Qalyubi, 2007: 61).

Kolaborasi Ilmu Perpustakaan dengan keilmuan lainnya telah menjadikan revolusi pemikiran mengenai perpustakaan. Hal ini dapat dilihat ketika Ranganathan seorang ahli matematika dari India pada tahun 1931 mengeluarkan konsep Five Laws of Library Science (Zulaikha, 2008:76). Konsep tersebut masih diakui hingga saat ini dan berimplikasi terhadap konsep layanan perpustakaan. Seiring dengan adanya perkembangan teknologi informasi, web dan internet maka Ilmu Perpustakaan juga mengalami revolusi sistem, di mana yang semula konsep manual menjadi terautomasi, konsep buku kertas menjadi buku digital, dan akan terus berkembang sesuai dengan keilmuan yang ada.

Dalam sejarah pengembangan Ilmu Perpustakaan selain Ranganathan banyak tokoh yang muncul dengan pemikiranpemikirannya, salah satunya adalah Michael Gorman. Beliau merupakan orang visioner terhadap perkembangan Ilmu Perpustakaan dan dunia kepustakawanan. Dengan pengalaman yang sangat banyak, baik ketika di Inggris dan Amerika menjadikan Gorman mempunyai pengaruh penting dalam dunia kepustakawanan terutama dalam bidang katalogisasi. Dia berkontrubusi aktif dalam pengembangan aturan katalogisasi AACR. Selain itu Gorman mengeluarkan gagasan-gagasan yang menarik di berbagai buku yang dia karang di antaranya adalah Eight Central Values of Librarianship, Five New Laws of Librarianship dan Spirituality in Librarianship.
Salah satu pemikiran yang menarik yang dikemukakan Gorman adalah Five New Laws of Librarianship. Dalam pemikiran ini Gorman mencoba memutakhirkan konsep yang sebelumnya dikemukakan oleh Ranganathan dalam Five Laws of Library Science (1931). Untuk lebih mengetahui seberapa jauh konsep yang dikemukaan Michael Gorman maka perlu dikaji lebih lanjut mengenai biografi dan pemikirannya dalam bidang perpustakaan beserta penjelasan konsep dari Five New Laws of Librarianship. Hal yang tak kalah penting adalah bagaimana konsep pemikiran Gorman dapat direfleksikan ke dalam dunia perpustakaan Indonesia saat ini.

\section{TINJAUAN LITERATUR DAN ANALISIS}

\section{a. Biografi Singkat Michael Gorman}

Dalam dokumen yang dikeluarkan oleh Henry Madden Library (2005) dijelaskan bahwa Michael Gorman lahir pada 6 Maret 1941 di Whitney, Oxfordshire, Inggris dan mulai menekuni dunia perpustakaan ketika bekerja di Perpustakaan Hendon. Awal pendidikan perpustakaan dimulai dengan kursus selama 2 tahun 1964-1966 di Ealing Technical College (sekarang Thames Universitas Valley). Pada masa kursus Michael Gorman mempunyai prestasi gemilang dengan mendapat penghargaan Cawthorne karena mendapatkan nilai terbaik ketika ujian tengah semester. Karir Profesionalnya dimulai dengan bekerja di Perpustakaan Nasional Inggris pada bagian bibliografi (1966-1972), kemudian pada bagian sekertariat perencanaan (1972-1974), dan akhirnya sebagai kepala kantor standar bibliografi (1974-1977).

Kemudian dari tahun 1977 hingga 1988 ia menjabat sebagai Direktur teknis layanan di Perpustakaan Universitas 
Illinois di Urbana, dan pada tahun 1988 sampai tahun 2007 dia menjadi Dekan Layanan Perpustakaan di Perpustakaan Henry Madden, California State University. Sepanjang karir perpustakaan beliau juga mengajar di pendidikan Ilmu Perpustakaan baik di Inggris ataupun Amerika.

Gorman sangat aktif dalam dunia kepustakawanan dengan mengikuti beberapa Asosiasi Perpustakaan baik di Inggris, Amerika maupun Internasional di antaranya ALA (American Library Association) dan LITA (Library Information Technology Association). Menjabat sebagai presiden LITA pada tahun 1990-2000 kemudian sebagai President Elect ALA tahun 2005-2006. Beliau juga merupakan pengarang, editor dari banyak buku dan monograf. Gorman berkontribusi sebagai editor dari AACR Second Edition (1978) dan revisinya (1988), kemudian AACR2 edisi ketiga tahun 1999 dan edisi keempat tahun 2005. Mengarang berbagai buku di antaranya, Future Libraries: Dreams, Madness, and Reality (1995), Our Enduring Values (2000) dan Our Own Selves: More Meditations for Librarians (2005). Selain itu, Gorman berkontibusi aktif dalam mengarang ratusan artikel dan paper di berbagai jurnal.

\section{b. Pemikiran Michael Gorman}

Gorman (2015:xiii) dalam Our Enduring Values Resivited mengungkapkan bahwa "Librarians have a duty, now more than ever, to revisit the values that inform our profession and to organize convincing rebuttals to anti-library arguments.". Dari pernyataan Gorman tersebut kita perlu menyadari bahwa tugas profesi pustakawan saat ini memang jauh berbeda dari masa sebelumnya, saat ini perkembangan teknologi informasi telah membawa persepsi berbeda bagi pemustaka. Perpustakaan terancam menjadi second opinion karena informasi begitu mudah dicari dengan memanfatkan teknologi informasi. Akan tetapi, di lain sisi teknologi informasi juga bisa menjadi peluang untuk terus mengembangkan perpustakaan. Menghadapi perubahan fungsi pustakawan tersebut maka muncullah pemikiran Gorman tentang New Five Laws of Library Science.

Kelima pemikiran Gorman tersebut adalah:

1. Libraries serve humanity,

2. Respect all forms by which knowledge is communicated,

3. Use technology intelligently to enhance service,

4. Protect free access to knowledge,

5. Honor the past and create the future.

Hukum Pertama dari Gorman adalah libraries serve humanitiy, kata kunci dari hukum yang pertama ini adalah pelayanan. Prinsip dasar perpustakaan adalah pelayanan baik terhadap individu, kelompok, dan masyarakat secara keseluruhan. Dengan pelayanan yang humanis akan mendapatkan aspirasi dari pemustaka. Pelayanan humanis yang dimaksud adalah pelayanan yang bertumpu pada kualitas sehingga pelayanan yang diberikan oleh perpustakaan mampu melebihi harapan dari pemustaka. Dalam sebuah sebuah pelayanan yang humanis diperlukan dorongan psikis untuk melayani.

Hukum Kedua adalah respect all forms by which knowledge is communicated, banyak mitos yang muncul yang menyatakan bahwa era buku akan mati dan digantikan dengan teknologi dan akan muncul komunitas paperless. Gorman menekankan bahwa hal yang terbaik adalah menghormati semua bentuk sarana 
komunikasi ilmu pengetahuan karena masing-masing mempunyai kelebihan dan kelemahan. Faktanya menurut Gorman (1995:784) perpustakaan di masa depan akan tetap menggunakan berbagai jenis sumber ilmu pengetahuan dan informasi. Pada dasarnya media komunikasi yang baru adalah untuk melengkapi dan meningkatkan media yang telah ada sebelumnya, walaupun faktanya sarana komunikasi baru akan menimbulkan suatu pandangan untuk menghilangkan sarana sebelumnya.

Saat ini tidak ada alasan untuk menolak teknologi dengan berpegang teguh bahwa mencetak haruslah di kertas atau membuat gambar dengan film. Dalam beberapa kasus, teknologi menawarkan alternatif biaya dan manfaat (Gorman, 1995:784). Akan tetapi kita juga memiliki alternatif lain ketika teknologi dipandang terlalu mahal atau memiliki kelemahan, yaitu dengan menggunakan teknologi sebelumnya. Yang paling penting perpustakaan haruslah bisa mengkolaborasikan alternatif-alternatif tersebut.

Hukum Ketiga adalah use technology intelligently to enhance service, Gorman menjelaskan bahwa sejarah kemajuan dalam kepustakawanan telah menjadi kisah keberhasilan integrasi antara sarana teknologi dan komunikasi baru ke dalam program dan layanan yang ada di perpustakaan. Penggunaan teknologi secara cerdas lebih diartikan untuk mencari jawaban dari masalah daripada mencari aplikasi teknologi baru yang menarik, menimbang efektivitas biaya dengan menghitung antara biaya dan manfaat yang diperoleh, memikirkan dampak dari setiap usulan inovasi layanan, dan memikirkan kembali program layanan (Gorman, 1995:785).
Hukum Keempat adalah protect free access to knowledge. Perpustakaan sebagai pusat kebebasan sosial, politik, dan intelektual haruslah menyediakan layanan yang bebas dari berbagai sensor. Perpustakaan diharapkan bisa menjadi penjaga dari kebebasan intelektual (Gorman, 1995:785). Perpustakaan haruslah mampu menyediakan informasi bagi masyarakat pengguna, yang paling penting dalam konsep ini adalah kecepatan dalam menyediakan informasi. Hal ini penting guna membangun kepercayaan pengguna layanan.

Hukum Kelima adalah honor the past and create the future, $\mathrm{di}$ mana menghasilkan sebuah diskusi mengenai dua sudut pandang masa depan perpustakaan. Sudut pandang pertama adalah pustakawan yang menolak dengan adanya teknologi terbaru. Sedangkan sudut pandang yang kedua adalah mencemooh teknologi di masa lalu. Dari sudut pandang Gorman, hal tersebut harus dicarikan titik temu yaitu dengan mempertahankan yang baik di masa lalu dan diimbangi dengan inovasi untuk masa depan (Gorman, 1995:785). Seiring perkembangan zaman, beberapa konsep memang mengalami perkembangan seperti: koleksi perpustakaan, layanan perpustakaan dan teknologi di perpustakaan. Untuk itu beberapa konsep dan teknologi lama yang tidak bermanfaat lagi haruslah dibuang, tetapi hal-hal lama yang masih bermanfaat haruslah tetap dilanjutkan. Adapun konsep dan teknologi baru tidak selamanya baik dan tidak selamanya buruk, untuk itu perlu dievaluasi dari segi manfaat dan biaya. Gorman (1998:69) menjelaskan bahwa seseorang yang bijak akan mengerti masa lalu perpustakaan, tahu perkembangan perpustakaan, dan bisa membangun sebuah masa depan perpustakaan berdasarkan tradisi dan inovasi. 


\section{c. Revolusi Pemikiran Michael Gorman}

Pemikiran Gorman tentang Five New Laws of Librarianship adalah mencoba untuk menginterpretasikan kembali kebenaran dari konsep Ranganathan dalam konteks perpustakaan hari ini dan masa depan. Zulaikha (2008:76) menyatakan bahwa sebenarnya konsep Ranganathan tentang Five Laws of Library Science masihlah sangat relevan dengan konteks perpustakaan saat ini. Akan tetapi di sini Gorman mencoba untuk menawarkan pemikiran barunya mengenai kepustakawanan. Pemikiran Gorman ini berdasarkan asumsi penulis, muncul dikarenakan isu-isu yang berkembang di perpustakaan baik mengenai konsep pelayanan, konsep penerapan teknologi informasi, dan konsep kebebasan intelektual. Adapun perkembangan dari konsep tersebut ada dalam tabel di bawah ini.

Tabel 1. Five Laws of Library Science dan Five New Laws of Librarianship

\begin{tabular}{|l|l|l|}
\hline Five Laws & $\begin{array}{l}\text { S.R. } \\
\text { Ranganathan }\end{array}$ & Michael Gorman \\
\hline $\begin{array}{l}\text { The First } \\
\text { Law }\end{array}$ & Books are for use. & $\begin{array}{l}\text { Libraries serve } \\
\text { humanity }\end{array}$ \\
\hline $\begin{array}{l}\text { The Second } \\
\text { Law }\end{array}$ & $\begin{array}{l}\text { Every person his } \\
\text { or her book. }\end{array}$ & $\begin{array}{l}\text { Respect all forms } \\
\text { by which } \\
\text { knowledge is } \\
\text { communicated }\end{array}$ \\
\hline $\begin{array}{l}\text { The Third } \\
\text { Law its }\end{array}$ & $\begin{array}{l}\text { Every book } \\
\text { reader. } \\
\text { The Fourth }\end{array}$ & $\begin{array}{l}\text { Save the time of } \\
\text { the reader. } \\
\text { entelligently to service }\end{array}$ \\
\hline $\begin{array}{l}\text { The Fifth } \\
\text { Law }\end{array}$ & $\begin{array}{l}\text { The library is a a } \\
\text { growing } \\
\text { organism. }\end{array}$ & $\begin{array}{l}\text { Honor the access } \\
\text { and create the } \\
\text { future }\end{array}$ \\
\hline
\end{tabular}

Dalam konsep Ranganathan kata kunci yang dipakai adalah buku, pemustaka, dan perpustakaan. Dalam perkembangan konsep five laws of library science sendiri telah dilakukan penggantian subyek utama menjadi subyek lain. Selain dikembangkan oleh Gorman konsep ini juga dikembangkan antara lain oleh Alireza Noruzi dengan konsep Application of Ranganathan's Laws to the Web, kemudian K.R. Srivathsan dengan konsep Five Laws of Information Science and Information Dynamic, dan Mentor Cana dengan konsep Open Source and Ranganathan's Five Laws of Library Science. Melihat perkembangan dari konsep Ranganathan, B. K. Sen (2008:89) menganalisis perkembangan konsep tersebut dan menghasilkan lima poin penting, yaitu (1) hukum yang pertama berfokus pada item yang bermanfaat, (2) hukum kedua dan ketiga berfokus pada pengguna dan item yang dimanfaatkan, (3) hukum keempat merupakan daya tarik yang umum, (4) hukum kelima berfokus pada organisasi, (5) objek yang muncul dalam hukum pertama adalah komponen organisasi dari hukum kelima.

Perbedaan mendasar dari konsep Gorman dan Ranganathan pada hukum Pertama adalah tentang pelayanan dan pemanfaatan. Anwar (2014:16) menyatakan bahwa inti dari books for use adalah bagaimana buku dapat digunakan secara maksimal oleh pengguna, di mana perpustakaan harus memikirkan aspekaspek alat akses, perabot, pengaturan tempat, fasilitas, dan promosi. Sedangkan Gorman menekankan kepada pelayanan yang humanis sehingga menempatkan pustakawan melayani dengan dorongan psikis untuk memberikan layanan yang terbaik.

Dalam hukum yang Kedua Ranganathan menekankan kepada hakhak pemustaka untuk mendapatkan akses sumber-sumber informasi yang dibutuhkan. Berbeda dengan Gorman, dia lebih menekankan akan perpaduan media komunikasi ilmu pengetahuan untuk bisa 
sama-sama

dimanfaatkan

di perpustakaan.

Hukum Ketiga dari Ranganathan adalah every book its reader yang mencoba mengungkapkan cara-cara yang dilakukan perpustakaan dan pustakawan untuk menemukan pembaca dari setiap buku yang ada di perpustakaan. Gorman dalam hukum ketiga ini lebih menekankan terhadap pemanfaatan fungsi teknologi secara cerdas tentang fungsi teknologi dalam membantu mengembangkan perpustakaan.

Hukum Keempat menjadikan daya tarik dari konsep Ranganathan yaitu menghemat waktu pembaca berarti yang berarti menyediakan akses yang efisien dan teliti untuk mencari sumber informasi. Kunci dari konsep ini adalah kepuasan pemustaka. Hal ini berbeda dengan konsep Gorman yang menekankan arti pentingnya perpustakaan untuk bisa benar-benar menjadi pusat intelektual sehingga harus memberikan akses ke berbagai sumber informasi. Apa yang dikemukakan Gorman ini menempatkan kepercayaan pengguna sebagai kunci dari layanan. Dengan adanya akses ke berbagai sumber informasi maka secara otomatis kepercayaan pemustaka dapat terbentuk dengan sendirinya.

Hukum Kelima yang dikemukakan Ranganathan menyatakan bahwa perpustakaan terus berkembang serta berubah dan akan selalu mengalami hal tersebut (Zulaikha, 2008:88). Konsekuensi dari hukum ini, perpustakaan harus mampu beradaptasi dari perkembangan zaman dan dengan berbagai kondisi, serta mampu beradaptasi dengan lingkungan sosial dan perkembangan teknologi. Hal ini berbeda jauh dengan konsep Gorman bahwa untuk menciptakan masa depan dan mengembangkan perpustaaan yang baik adalah dengan menghormati hal-hal baik dari masa lalu perpustakaan.

\section{d. Aplikasi Pemikiran Michael Gorman}

Terdapat banyak hal yang bisa diambil dari konsep Gorman tentang Five New Laws of Librarianship dalam aktualisasi dunia kepustakawanan di Indonesia. Dimulai dengan konsep layanan sebagai mana disebutkan dalam hukum yang pertama. Penggambaran pustakawan di Indonesia saat ini masih mempunyai citra yang belum baik. Pustakawan masih diposisikan sebagai profesi kutu buku dengan kesan jauh dari penampilan rapi dan melayani dengan tidak ramah. Dengan berpegang teguh pada konsep Gorman kita harus merubah citra pustakawan sebagai pribadi yang humanis karena prinsip utama dari sebuah pelayanan adalah melayani.

Pelayanan yang humanis haruslah menjadi ciri dari pustakawan masa kini. Pelayanan ini mengedepankan prinsip etika dan kaidah SOP yang telah disusun oleh pustakawan. Pustakawan diharuskan untuk selalu reaktif terhadap berbagai masalah yang dialami pemustaka dalam memanfaatkan layanan perpustakaan. Sehingga prinsip yang sering kita sebut dengan 3S (senyum, salam, sapa) dapat menjadi $4 S$ yaitu senyum, salam, sapa, dan service.

Hukum yang Kedua dari Michael Gorman memang menjadi gagasan menarik dan banyak dipakai dalam membangun sebuah perpustakaan dimana menggabungkan antara perpustakaan konvensional dan perpustakaan digital atau sering disebut dengan perpustakaan hibrida. Pengertian Perpustakaan Hibrida menurut Prytherch (2005:322) adalah: 
"A library that provides services in a mixedmode, electronic and paper, environment, particularly in a co-ordinated way. Derived from a strand of eLib which explored the issues surrounding the retrieval and delivery of information in these types of environments but also investigated the integration of different electronic services so that a single search approach could be offered to the End user."

$\begin{array}{ccc}\text { Berdasarkan } & \begin{array}{c}\text { pengertian di atas } \\ \text { perpustakaan }\end{array} & \text { adalah }\end{array}$
penggabungan antara koleksi tercetak dan digital yang dimiliki oleh perpustakaan. Pada bagian konseptual sebenarnya perpustakaan hibrida telah banyak dikembangkan di Indonesia. Hanya saja optimalisasi pencarian melalui satu portal pencarian untuk menemukan berbagai jenis koleksi baik tercetak dan digital baru beberapa saja yang memanfaatkan. Seperti Perpustakaan Universitas Gadjah Mada yang telah memanfaatkan fasilitas Summon, sehingga berbagai sumber daya informasi yang dimiliki baik tercetak maupun digital dapat ditelusur melalui satu portal yaitu http://ugm.summon.serialssolutions.com L.

Selain itu, saat ini Melah dikembangkan satu portal penelusuran yaitu Indonesia OneSearch (http://onesearch.id/). Melalui portal Indonesia OneSearch semua orang dapat menelusur berbagai macam koleksi, baik digital maupun data bibliografi koleksi tercetak dari perpustakaan mitra. Harapan ke depannya semua perpustakaan dapat tergabung dalam Indonesia OneSearch. Hal ini menjadi sangat penting karena sebagaimana prinsip Gorman, pengembangan perpustakaan tidaklah hanya menyediakan koleksi tetapi juga harus menyediakan akses ke koleksi baik yang dimiliki maupun tidak dimiliki (Crawford \& Gorman, 1995:153-154) .
Hukum Ketiga dari Gorman mengharuskan perpustakaan mampu mengimplementasikan teknologi secara cerdas. Saat ini software berbasis open source sedang menjadi trend di perpustakaan Indonesia. Hal yang cerdas yang dilakukan perpustakaan ketika memilih software berbasis open source adalah efisiensi dana, fleksibilitas pemakaian karena dapat dimodifikasi sesuai kebutuhan, dan sharing knowledge karena banyak komunitas yang terbentuk. Adapun beberapa contoh software open source yang banyak digunakan di perpustakan di antaranya Ubuntu dan Debian sebagai sistem operasi, SLiMS , INLIS Lite, dan Koha sebagai sistem otomasi, Eprints dan Dspace sebagai sistem perpustakaan digital , Joomla dan Drupal sebagai CMS Web.

Hukum Keempat dari Michael Gorman menempatkan perpustakaan sebagai pusat kebebasan intelektual. Dalam konteks sejarah kebebasan intelektual, penerbitan di Indonesia pernah mengalami masa kelam di mana saat orde baru banyak buku yang dilarang untuk terbit dan diedarkan. Hal ini bermula karena adanya UU No 4/PNPS/1963 tentang Pengamanan terhadap barang-barang cetakan yang isinya dapat mengganggu ketertiban umum. Pada perkembangannya kemudian diimplementasikan oleh orde baru dengan melakukan pelarangan buku melalui Instruksi Menteri Pendidikan Dasar dan Kebudayaan No. 1381/1965. Dalam instruksi tersebut dilampirkan daftar pengarang dan buku yang dilarang (Kartikasari \& Andayani, 2014:458).

Melihat fenomena ini maka perpustakaan mempunyai peran penting dengan melakukan dokumentasi dan pemberian akses terbatas terhadap buku yang dilarang. Hal tersebut tercermin dari sikap Badan Perpustakaan dan Arsip 
Daerah Yogyakarta yang mengkoleksi karya-karya yang pernah dilarang oleh pemerintah, dan ketika orde kekuasaan berakhir maka koleksi tersebut menjadi dapat diakses oleh masyarakat umum (Prabowo, 2015: 60).

Perkembangan terakhir Mahkamah Konstitusi telah dilakukan uji materi terhadap UU No 4/PNPS/1963. Melalui Putusan Nomor 6-13-20/PUU-VIII/2010 Mahkamah Konstitusi memutuskan bahwa UU No 4/PNPS/1963 tidak sesuai dengan semangat Undang-Undang Dasar 1945. Mahkamah Konstitusi juga memutuskan bahwa undang-undang tersebut tidak mempunyai kekuatan hukum dan penyitaan buku oleh kejaksaan harus melalui putusan pengadilan serta tidak melalui Kejaksaan Agung. Berdasarkan perkembangan situasi politik dan peraturan perundangundangan maka kebijakan perpustakaan untuk mengoleksi buku terlarang di masa depan sangatlah penting guna untuk menjamin kebebasan intelektual.

Hukum terakhir dari Gorman menjelaskan tentang penghormatan dari masa lalu perpustakaan yang bisa digunakan untuk membangun perpustakaan yang lebih baik dimasa depan. Dari segi penghormatan masa lalu, Perpustakaan selain menghimpun koleksi haruslah bisa mendokumentasikan berbagai sesuatu yang bernilai sejarah yang dimungkinkan akan berguna sebagai pertimbangan pengambilan keputusan di masa depan. Hal tersebut bisa berupa dokumentasi sejarah kepemimpinan perpustakaan, dokumentasi konsep pengembangan gedung perpustakaan, dan konsep layanan perpustakaan dari masa ke masa. Dari segi penerimaan inovasi untuk perkembangan perpustakaan perlu dianalisis lebih lanjut mengenai analisis biaya dan manfaat dari sebuah sistem teknologi. Hal konkrit yang muncul adalah ketika teknologi RFID mulai menggantikan teknologi barcode maka perlu dianalisis tentang kecukupan biaya serta manfaat yang diperoleh dari implementasi teknologi tersebut.

\section{KESIMPULAN}

Gorman mempunyai latar belakang serta pengalaman yang banyak dalam bidang perpustakaan, baik melalui pendidikan formalnya maupun melalui pengalaman-pengalaman profesionalnya. Dalam kehidupannya beliau telah banyak menyumbangkan pemikiran-pemikiran tentang kepustakawanan. Melalui pengalaman-pengalaman dalam bidang kepustakawanan Gorman mampu merefleksikan dan menyajikan kembali konsep Ranganathan ke dalam bentuk yang berbeda. Konsep Five New Laws of Librarianship yang dikemukakan Gorman tidak hanya sekedar menekankan pada konsep layanan perpustakaan masa kini, tetapi juga tidak melupakan pemanfaatan koleksi serta sarana prasarana pendukungnya. Perlu dicatat bahwa dalam konsep Gorman banyak disinggung mengenai fenomena teknologi di perpustakaan akan tetapi belum ditemukan konsep mengenai kompetensi pustakawan yang berkaitan dengan penguasaan teknologi.

Esensi yang dapat diambil dari konsep Gorman adalah penerapan konsep Five New Laws of Librarianship sangat relevan ketika diaktualisasikan ke dalam dunia perpustakaan di Indonesia. Mulai dari prinsip layanan, prinsip pengembangan jenis dan akses koleksi, prinsip pengembangan sarana dan prasana, prinsip kebebasan intelektual, dan terakhir prinsip penghargaan dari sejarah perpustakaan. Dengan mengaplikasikan konsep Gorman diharapkan perkembangan perpustakaan di Indonesia akan semakin maju. 


\section{DAFTAR PUSTAKA}

Anwar, A. (2014). Analisis Pengembangan Open Source Library Software Ditinjau Dari Konsep Five Laws of Library Science SR Ranganathan (Studi Kasus Software SLiMS) (Skripsi). Universitas Islam Negeri Sunan Kalijaga.

Crawford, W., \& Gorman, M. (1995). Future Libraries: Dreams, Madness \& Reality. Chicago: American Library Association.

Gorman, M. (2015). The Life of Libraries Continuing Our Work in The Digital Revolution. Retrieved September 30, 2017, from http:/ / americanlibrariesmagazine .org/2015/02/25/the-life-oflibraries/

Gorman, M. (1995). Five new laws of librarianship. American libraries, 26( 8), 784-785.

Gorman, M. (2015). Our Enduring Values Revisited: Librarianship in An Ever-Changing World. Chicago: American Library Association.

Gorman, M. (1998). Our singular strengths: Meditations for librarians. Chicago: American Library Association.

Henry Madden Library (2005). Michael Gorman (1941- ). Retrieved September 20, 2017, from http:/ / www.fresnostate.edu/libr ary/subjectresources/specialcolle ctions/Michael-Gormanpapers1.pdf

Kartikasari, D., \& Andayani, A. (2014). Pelarangan Buku-Buku Karya Sastrawan Lekra Tahun 1965-1968. Jurnal Mahasiswa Teknologi Pendidikan, 2(3). 453-465, available from http:/ jurnalmahasiswa.unesa.ac. id/index.php/avatara/article/vie $\mathrm{w} / 9068$
Mahkamah Konstitusi. (2010). PUTUSAN Nomor 6-13-20/PUU-VIII/2010. Retrieved from http:/ / lama.elsam.or.id/downloa ds/1287029577_Putusan_6-13-20PUU-VIII-2010.pdf

Prabowo, T.T. (2015) . Strategi Preservasi dan Konservasi Koleksi Terlarang Di BPAD Yogyakarta. Visi Pustaka 17(1), 53-61. Retrieved from dev.perpusnas.go.id/assets/uploa ds/2016/07/Thoriq_Strategi_Pres ervasi_Konservasi.pdf

Prytherch, R. (2005). Harrod's Librarians' Glossary and Reference Book: A Directory of Over 10,200 Terms, Organizations, Projects and Acronyms in The Areas of Information Management, Library Science, Publishing And Archive Management. Cornwall : MPG Books Ltd.

Qalyubi, S. (2007). Dasar-dasar Ilmu Perpustakaan dan Informasi. Yogyakarta: Jurusan Ilmu Perpustakaan dan Informasi, Fakultas Adab.

Ranganathan, S. R. (1931). The Five Laws of Library Science. London: Edward Goldston LTD.

Sen, B. K. (2008). Ranganathan Five Law. Annals of Library and Information Studies, 55(June), 87-90. Retrieved from

http:/ / nopr.niscair.res.in/bitstrea $\mathrm{m} / 123456789 / 1769 / 1 /$ ALIS\%205 5(2)\%2087-90.pdf

Zulaikha, S. R. (2008). Kontribusi S.R. Ranganathan dalam Perkembangan Ilmu Perpustakaan Dewasa Ini. Jurnal Fihris, 3(1)., 7588. Retrieved from http:/ / digilib.uinsuka.ac.id/259/ 